\title{
Phytochemical Content of Centaurea polypodiifolia boiss. var. polypodiifolia
}

\section{Ferda ESER *1, Ayse SAHIN YAGLIOGLU², Ebru AKTAS ${ }^{3}$, Adem ONAL $^{3}$, Ibrahim DEMIRTAS ${ }^{2}$}

${ }^{1}$ Department of Private Security and Protection, Suluova Vocational Schools, Amasya University, Amasya, Turkey

${ }^{2}$ Department of Chemistry, Faculty of Science, Cankiri Karatekin University, 18100 Cankiri, Turkey

${ }^{3}$ Department of Chemistry, Faculty of Science \& Art, Gaziosmanpasa University, 60240 Tokat, Turkey

Received: 04 May 2017 - Revised: 18 September 2017 - Accepted: 03 November 2017

\begin{abstract}
Various solvents including hexane, $\mathrm{CHCl}_{3}$, EtOAc, and $\mathrm{MeOH}$ were used to extract the aerial parts of C. polypodiifolia Boiss. var. polypodiifolia. Hexane extract was analyzed by GC-MS and nonacosane and octacosane were determined as the main constituents. HPLC-TOF/MS analyses were carried out on $\mathrm{CHCl}_{3}$, EtOAc, and $\mathrm{MeOH}$ extracts. The main constituents of $\mathrm{CHCl}_{3}$ extract were detected as 4-hydroxybenzoic acid, vanilic acid, and gentisic acid. Gentisic acid, fumaric acid, chlorogenic acid, and vanilic acid were determined as the main compounds of EtOAc extract. Finally, main constituents of $\mathrm{MeOH}$ extract were found as fumaric acid, chlorogenic acid, quercetin-3- $\beta$-D-glucoside, gentisic acid and diosmin.
\end{abstract}

Keywords: Centaurea polypodiifolia, extract, GC-MS, HPLC-TOF/MS

\section{INTRODUCTION}

The genus Centaurea which belongs to Asteraceae family, comprises nearly 500 species around the World [1]. Centaurea species are generally used in folk medicine due to their pharmacological properties such as fever treatment, diabetes, hemoroid, and peptid ulcer [2]. Biological activity studies of Centaurea genus revealed that they have exhibited antioxidant, antimicrobial and antipyretic activities [3].

Phytochemical studies of Centaurea species showed that the main compound groups of different Centaurea species were sesquiterpenes [4-8], lignin compounds [9-11], flavonoids [12-14], and their glycosides. Secondary metabolites especially phenolic compounds are responsible from the biological [15-18] activities. Phenolic and flavonoid compounds, as important phytochemicals, are present in vegetables, fruits and cereal grains. Phytochemicals such as phenolic and flavonoid compounds commonly found in plants have multiple biological effects and play an important role in the defense against cardiovascular disease, aging and cancer [19]. In recent years, the studies related with plant-derived phytochemicals and their biological activities have gained interest that they give natural solutions for health-care [20].

\footnotetext{
*Corresponding Author E-mail: ferda.eser@amasya.edu.tr
} 
Therefore, determination of the phytochemical content of the plants is an important step for the treatment and prevention of some diseases.

The objective of the current study is to determine the phytochemical content of different extracts of Centaurea polypodiifolia boiss. var. polypodiifolia. So, it facilitates the future investigations related with biological activity.

\section{MATERIAL and METHODS}

\subsection{General Experimental Procedures}

GC-MS analysis was performed with a Perkin Elmer Clarus 500 Series GC system. Phenolic constituents of the extracts were determined using an Agilent Technologies 6210 Time-of-Flight LC-MS. All solvents used in HPLC analysis were of HPLC grade and purchased from Merck. The extraction solvents were distilled before the extraction processes.

\subsection{Plant Material}

C. polypodiifolia Boiss. (CPP) was collected from Karacayir/Sivas (39 5129 N, 365848 E, $1568 \mathrm{~m}$ ). Identification of the plant material was performed by Prof. Dr. Necati CELIKK from Cumhuriyet University and Prof. Dr. Neriman OZHATAY from Istanbul University. A vouchermen deposited the plant material in the herbarium of Cumhuriyet University and Istanbul University, respectively (CUFH 8934; ISTE 85428).

\subsection{Extraction Procedure}

Flowers of CPP $(100 \mathrm{~g})$ were extracted with hexane $(1 \mathrm{~L} \mathrm{x} 3)$ for $24 \mathrm{~h}$. After the process, it was filtered and evaporated. The residue was re-extracted with the same procedure for the following solvents $\mathrm{CHCl}_{3}$, EtOAc, and $\mathrm{MeOH}$, respectively.

\subsection{Methylation Procedure}

The fatty acid composition of hexane extract was determined by using methylation of the lipid extracts to form fatty acid methyl esters (FAME) for gas chromatography (GC) analysis. For this purpose, $40 \mathrm{mg}$ of extracted oil was dissolved in a tube which contained $\mathrm{n}$-heptane. Then, $2 \mathrm{M} \mathrm{KOH}(2 \mathrm{~mL})$ was added to the tube, the mixture was shaken vigorously and allowed to reach formation of phases. The upper layer, which contained the FAME was transferred to a vial and diluted with n-hexane for GC analyses [21].

\subsection{Gas Chromatography (GC) Analysis}

FAME analyses were carried out with a Perkin Elmer Clarus 500 Series GC system equipped with flame ionization detector (FID) and a TR-FAME apolar capillary column (30 m x $0.25 \mathrm{~mm}$ and $0.25 \mathrm{~m} \mathrm{ID)}$. The split ratio was 50:1 port. Helium was used as the carrier gas at a flow rate of $0.5 \mathrm{~mL} / \mathrm{min}$. The temperatures of the injector and detector were set to 250 and $260{ }^{\circ} \mathrm{C}$, respectively. An initial column oven temperature of $100{ }^{\circ} \mathrm{C}$ was raised to $220{ }^{\circ} \mathrm{C}$ at a rate of $2{ }^{\circ} \mathrm{C} / \mathrm{min}$. Identification of the FAME peaks was performed by comparing the retention times of each peak with those of authentic standards (Supelco 37 Comp. Fatty acid Mix, 18919) and their mass spectral

\subsection{HPLC-TOF/MS Analysis}

Phenolic constituents of the plant extracts were determined in an Agilent 1260 Infinity HPLC system coupled with an Agilent 6210 TOF-MS detector and an VYDAC C18 column $(25 \mathrm{~mm} \times 300 \mathrm{~mm} 10 \mu \mathrm{m}$ ). Water (with $2.5 \%$ formic acid) and acetonitrile were used for the mobile phases, $\mathrm{A}$ and $\mathrm{B}$, respectively. The column temperature was adjusted to $35^{\circ} \mathrm{C}$ where the flow rate was $0.8 \mathrm{~mL} \mathrm{~min}^{-1}$. The injection volume was $200 \mu \mathrm{L}$ and the elution program was as 
follows: 0-1 $\min , 10 \% \mathrm{~B} ; 1-12 \mathrm{~min}, 40 \% \mathrm{~B} ; 12-14 \mathrm{~min}, 90 \% \mathrm{~B} ; 14-17 \mathrm{~min}, 90 \% \mathrm{~B} ; 17-18$ min, $10 \% \mathrm{~B} ; 18-25 \mathrm{~min}, 10 \% \mathrm{~B}$.

\section{RESULTS}

\subsection{Fatty Acid Content}

GC-MS analysis results of the hexane extract of CPP was given in Table 1. Main constituent of the hexane extract of CPP was assigned as nonacosane (43.53\%).

Table 1. Fatty acid contents of the hexane extract of CPP

\begin{tabular}{|c|c|c|c|}
\hline No & RT & Compound & Area $(\%)$ \\
\hline \multicolumn{4}{|c|}{ Saturated fatty acids } \\
\hline 1 & 19.771 & Lauric acid & 0.51 \\
\hline 2 & 22.804 & Myristic acid & 1.21 \\
\hline 3 & 27.456 & Palmitic acid & 3.76 \\
\hline 4 & 32.491 & Stearic acid & 0.85 \\
\hline 5 & 34.763 & Arachidic acid & 1.05 \\
\hline 6 & 37.2 & Behenic acid & 0.86 \\
\hline 7 & 38.688 & Tricosylic acid & 0.12 \\
\hline 8 & 40.468 & Lignoceric acid & 0.50 \\
\hline 9 & 45.383 & Cerotic acid & 0.33 \\
\hline 10 & 65.035 & Melissic acid & 0.19 \\
\hline \multicolumn{4}{|c|}{ Mono unsaturated fatty acid } \\
\hline 11 & 32.188 & Oleic acid & 2.85 \\
\hline \multicolumn{4}{|c|}{ Poly unsaturated fatty acid } \\
\hline 12 & 32.096 & Linoleic acid & 2.28 \\
\hline \multicolumn{4}{|c|}{ Other compounds } \\
\hline 13 & 19.903 & Myristicin & 1.41 \\
\hline 14 & 25.138 & 3,7,11,15-Tetramethyl-2-hexadecen-1-ol & 0.15 \\
\hline 15 & 25.304 & Hexahydrofarnesyl acetone & 0.13 \\
\hline 16 & 32.342 & Phytol & 0.40 \\
\hline 17 & 33.315 & Docosane & 0.27 \\
\hline 18 & 34.448 & Tricosane & 3.76 \\
\hline 19 & 34.683 & 11-Eicosenoic acid, methyl ester & 0.43 \\
\hline 20 & 35.552 & Tetracosane & 0.70 \\
\hline 21 & 35.924 & Methyl 14-methyl-eicosanoate & 0.11 \\
\hline 22 & 36.8 & Pentacosane & 3.11 \\
\hline 23 & 37.126 & Methyl 11-docosenoate & 0.18 \\
\hline 24 & 38.167 & Hexacosane & 0.47 \\
\hline 25 & 39.964 & Octacosane & 16.42 \\
\hline 26 & 44.788 & Nonacosane & 43.53 \\
\hline 27 & 45.583 & $\begin{array}{l}\text { 8-Androsten-3-ol, } 17-(2-m e t h y l a l l y l)-4,4,14- \\
\text { trimethyl- }\end{array}$ & 0.22 \\
\hline 28 & 47.488 & Triacontane & 1.76 \\
\hline 29 & 51.608 & Tetratriacontane & 9.29 \\
\hline 30 & 56.197 & Hexatriacontane & 0.30 \\
\hline 31 & 59.934 & Stigmasterol & 0.49 \\
\hline 32 & 62.406 & Hentriacontane & 0.67 \\
\hline 33 & 63.504 & $\gamma$-Sitosterol & 0.92 \\
\hline 34 & 65.501 & $\beta$-Amyrin & 0.15 \\
\hline \multirow[t]{2}{*}{35} & 68.694 & $\alpha$-Amyrin & 0.48 \\
\hline & & Total & 99.86 \\
\hline
\end{tabular}




\subsection{Phenolic Compounds of the CPP Extracts}

The study was conducted to investigate the phenolic compounds of $\mathrm{CHCl}_{3}$, EtOAc, and $\mathrm{MeOH}$ extracts of CPP. The phenolic compound profile of CPP extracts were given in Table 2 . The results of the HPLC-TOF/MS analysis revealed that the main constituents of $\mathrm{CHCl}_{3}$ extract were 4-hydroxybenzoic acid $\left(0.168 \mathrm{~g} \mathrm{~kg}^{-1}\right)$, followed by vanilic acid $\left(0.133 \mathrm{~g} \mathrm{~kg}^{-1}\right)$, and gentisic acid $\left(0.112 \mathrm{~g} \mathrm{~kg}^{-1}\right)$. Main phenolic compounds of EtOAc extract were gentisic acid $\left(1.220 \mathrm{~g} \mathrm{~kg}^{-}\right.$ ${ }^{1}$ ), fumaric acid $\left(0.990 \mathrm{~g} \mathrm{~kg}^{-1}\right)$, chlorogenic acid $\left(0.866 \mathrm{~g} \mathrm{~kg}^{-1}\right)$, and vanilic acid $\left(0.571 \mathrm{~g} \mathrm{~kg}^{-1}\right)$. HPLC-TOF/MS results of MeOH extract showed that the main constituents of the extracts were fumaric acid (137.010 $\left.\mathrm{g} \mathrm{kg}^{-1}\right)$, chlorogenic acid $\left.\mathrm{g} \mathrm{kg}^{-1}\right)$, quercetin-3- $\beta$-D glucoside $\left(4.407 \mathrm{~g} \mathrm{~kg}^{-}\right.$ $\left.{ }^{1}\right)$, gentisic acid $\left(2.567 \mathrm{~g} \mathrm{~kg}^{-1}\right)$, and diosmin $\left(1.954 \mathrm{~g} \mathrm{~kg}^{-1}\right)$, respectively. It is observed that, while the main phenolic constituents of $\mathrm{MeOH}$ extract are determined as fumaric acid, chlorogenic acid, quercetin-3- $\beta$-D glucoside, gentisic acid, and diosmin; EtOAc extract doesn't contain these phenolics except gentisic acid (Table 2).

Table 2. Phenolic compounds of CPP extracts determined by HPLC-TOF/MS

\begin{tabular}{lllc}
\hline & & $\mathrm{CPP}$ & \\
Compound & $\mathrm{CHCl}_{3}(\mathrm{~g} / \mathrm{kg})$ & $\mathrm{EtOAc}(\mathrm{g} / \mathrm{kg})$ & $\mathrm{MeOH}(\mathrm{g} / \mathrm{kg})$ \\
\hline Chlorogenic acid & & 0.866 & 16.305 \\
4-hydroxybenzaldehyde & & 0.020 & \\
Vanilic acid & 0.133 & 0.571 & 0.797 \\
Gentisic acid & 0.112 & 1.220 & 2.567 \\
4-hydroxybenzoic acid & 0.168 & 0.404 & 1.533 \\
Kafeic acid & & 0.333 & 0.756 \\
Rutin & & & 0.021 \\
Protocatechuic acid & 0.011 & 0.184 & 0.951 \\
Naringenin & & 0.046 & 0.411 \\
Salisilic acid & 0.007 & 0.005 & \\
Wogonin & & & \\
Fumaric acid & & 0.990 & 137.010 \\
Quercetin-3- $\beta$-D glucoside & & 0.287 & 4.407 \\
Sinapic acid & & 0.081 & 0.143 \\
Diosmin & & 0.364 & 1.954 \\
Morin & & 0.129 & 0.634 \\
\hline
\end{tabular}

The standard compounds used for HPLC-TOF/MS analysis include the following phenolics besides the phenolics in Table 2: hesperidin, apigenin-7-glucoside, rosmarinic acid, protocatechuic acid ethyl ester, caftaric acid, quercetin, $p$-coumaric acid, kaempferol, ferulic acid, chicoric acid, ellagic acid, resveratrol, biochanin, eupatorin, cinnamic acid, syringic acid, apigenin, scutellarin, and neohesperidin. The HPLC-TOF/MS chromatograms of the CPP extracts were shown in Figure 1. 


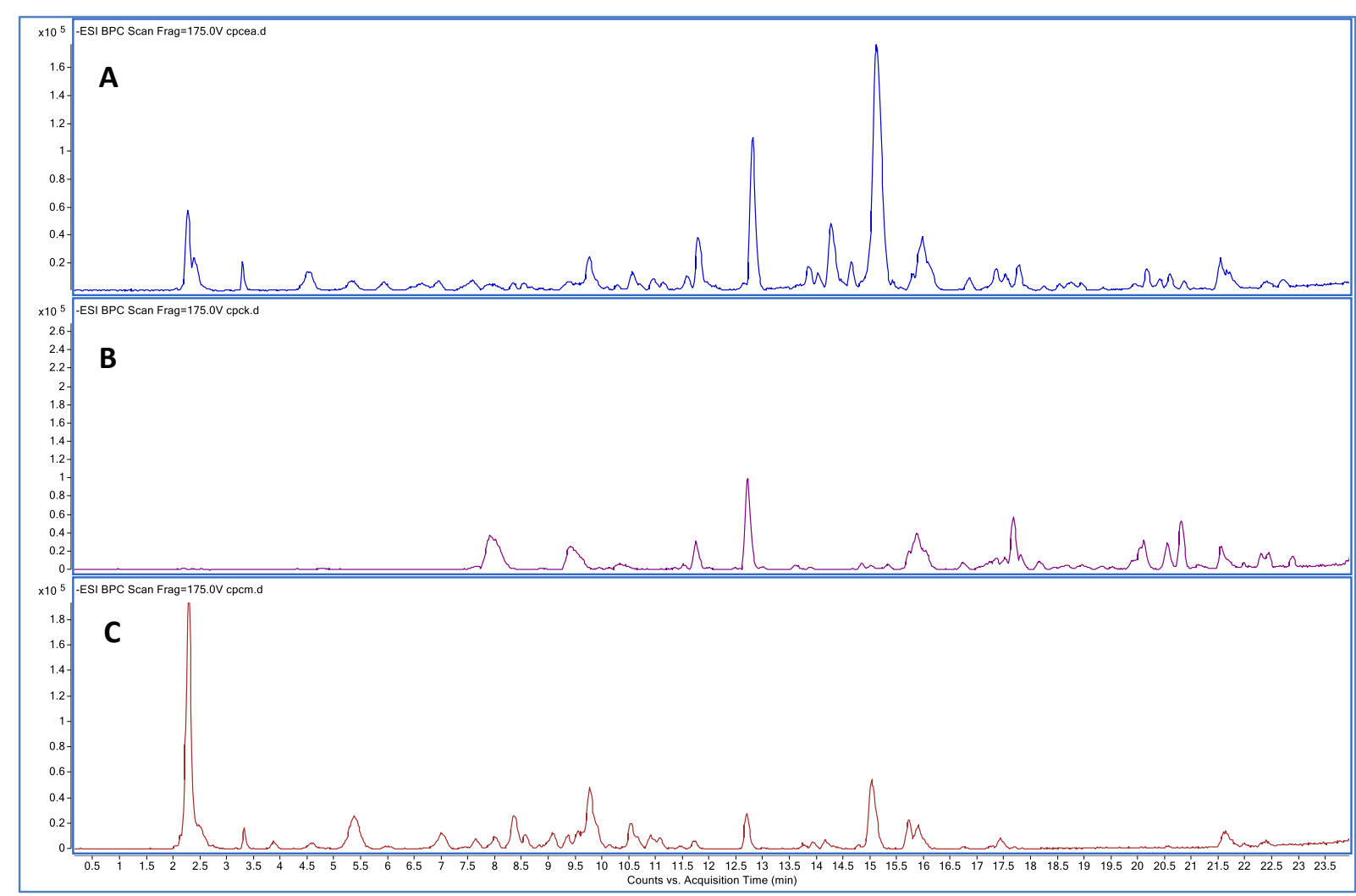

Figure 1. HPLC-TOF/MS chromatograms of $\mathrm{CHCl}_{3}$ (A), EtOAc (B), and $\mathrm{MeOH}(\mathrm{C})$ extracts of CPP

\section{CONCLUSION}

The presence of the phytochemicals plays an important role in the treatment or prevention of many diseases due to their potential biological activities. Therefore, it is important to know the phytochemical content of plants. In this study, different extracts of the flowers of Centaurea polypodiifolia Boiss. var. polypodiifolia were screened for their secondary metabolite contents using GC-MS and HPLC-TOF/MS, respectively. The results demonstrated that the main constituent of the hexane extract was nonacosane. Main phenolic compounds of $\mathrm{CHCl}_{3}, \mathrm{EtOAc}$, and $\mathrm{MeOH}$ extracts were determined as 4-hydroxybenzoic acid, gentisic acid, and fumaric acid, respectively.

\section{Acknowledgements}

This study was funded by Scientific Research Projects, Gaziosmanpasa University, Turkey (2015/92). We thank to Prof. Dr. Necati Celik from Cumhuriyet University and Prof. Dr. Neriman Ozhatay from Istanbul University for identification of the plant material. We also thank to Huseyin Aksit for his help in analyses.

\section{Conflict of Interests}

Authors declare that there is no conflict of interests.

\section{REFERENCES}

[1]. Dittrich, M. (1977). Cynareae systematic review. Biology and Chemistry of the Compositae.

[2]. Kargıoğlu, M., Cenkci, S., Serteser, A., Evliyaoğlu, N., Konuk, M., Kök, M. Ş., \& Bağc1, Y. (2008). An ethnobotanical survey of inner-West Anatolia, Turkey. Human Ecology, 36(5), 763-777. 
[3]. Reyhan, A., Küpeli, E., \& Ergun, F. (2004). The biological activity of Centaurea L. species. Gazi University Journal of Science, 17(4), 149-164.

[4]. Bruno, M., Maggio, A., Paternostro, M. P., Rosselli, S., Arnold, N. A., \& Herz, W. (2001). Sesquiterpene lactones and other constituents of three Cardueae from Cyprus. Biochemical systematics and ecology, 29(4), 433-435.

[5]. Bruno, M., Maggio, A., Rosselli, S., Gedris, T. E., \& Herz, W. (2002). Sesquiterpene lactones and other constituents of Centaurea paniculata ssp. castellana. Biochemical systematics and ecology, 30(4), 379-381.

[6]. Bruno, M., Rosselli, S., Maggio, A., Raccuglia, R. A., \& Arnold, N. A. (2005). Guaianolides from Centaurea babylonica. Biochemical systematics and ecology, 33(8), 817-825.

[7]. Cardona, M. L., Fernández, I., Pedro, J. R., \& Pérez, B. (1991). Sesquiterpene lactones and flavonoids from Centaurea aspera. Phytochemistry, 30(7), 2331-2333.

[8] Karamenderes, C., Konyalioglu, S., Khan, S., \& Khan, I. A. (2007). Total phenolic contents, free radical scavenging activities and inhibitory effects on the activation of NFkappa B of eight Centaurea L. species. Phytotherapy Research, 21(5), 488-491.

[9] Middleton, M., Cox, P. J., Jaspars, M., Kumarasamy, Y., Nahar, L., Reid, R., \& Sarker, S. D. (2003). Dibenzylbutyrolactone lignans and indole alkaloids from the seeds of Centaurea nigra (Asteraceae). Biochemical systematics and ecology, 31(6), 653-656.

[10] MacManus, S. M., Sarker, S. D., Shoeb, M., Majinda, R. R. T., \& Jaspars, M. (2004). Epoxylignans from the seeds of Centaurea cyanus (Asteraceae).

[11] Shoeb, M., MacManus, S. M., Kumarasamy, Y., Jaspars, M., Nahar, L., Thoo-Lin, P. K., \& Sarker, S. D. (2006). Americanin, a bioactive dibenzylbutyrolactone lignan, from the seeds of Centaurea americana. Phytochemistry, 67(21), 2370-2375.

[12] Akkal, S., Benayache, F., Bentamene, A., Medjroubi, K., Seguin, E., \& Tillequin, F. (2003). Flavonoid aglycones from Centaurea napifolia. Chemistry of natural compounds, 39(2), 219-220.

[13] Gonnet, J. F. (1993). Flavonoid glycoside variation in wild specimens of Centaurea triumfetti (Compositae) and comments on its relationships with Centaurea montana based on flavonoid fingerprints. Biochemical systematics and ecology, 21(3), 389-396.

[14] Kaij-a-Kamb, M., Amoros, M., \& Girre, L. (1992). The chemistry and biological activity the the genus Centaurea. Pharmaceutica Acta Helvetiae, 67(7), 178.

[15] Balasundram, N., Sundram, K., \& Samman, S. (2006). Phenolic compounds in plants and agri-industrial by-products: Antioxidant activity, occurrence, and potential uses. Food chemistry, 99(1), 191-203.

[16] Maddox, C. E., Laur, L. M., \& Tian, L. (2010). Antibacterial activity of phenolic compounds against the phytopathogen Xylella fastidiosa. Current microbiology, 60(1), 53.

[17] Nitiema, L. W., Savadogo, A., Simpore, J., Dianou, D., \& Traore, A. S. (2012). In vitro antimicrobial activity of some phenolic compounds (coumarin and quercetin) against gastroenteritis bacterial strains. Int J Microbiol Res, 3(3), 183-7.

[18] Yanez, J., Vicente, V., Alcaraz, M., Castillo, J., Benavente-Garcia, O., Canteras, M., \& Teruel, J. A. L. (2004). Cytotoxicity and antiproliferative activities of several phenolic compounds against three melanocytes cell lines: relationship between structure and activity. Nutrition and cancer, 49(2), 191-199.

[19] Karimi, E., Oskoueian, E., Hendra, R., \& Jaafar, H. Z. (2010). Evaluation of Crocus sativus L. stigma phenolic and flavonoid compounds and its antioxidant activity. Molecules, 15(9), 6244-6256. 
[20] Johnson, S. K., \& Blanchard, A. (2006). Alternative medicine and herbal use among university students. Journal of American College Health, 55(3), 163-168.

[21] Demirtas, I., Ayhan, B., Sahin, A., Aksit, H., Elmastas, M., \& Telci, I. (2011). Antioxidant activity and chemical composition of Sideritis libanotica Labill. ssp. linearis (Bentham) Borm.(Lamiaceae). Natural product research, 25(16), 1512-1523. 